\title{
INVERTIBILITY FOR SPECTRAL TRIANGLES
}

\author{
ROBIN HARTE AND CORA STACK
}

Abstract. A spectral inclusion for block triangles is extended to "spectral" triangles.

Mathematics subject classification (2000): 47A10.

Key words and phrases: Banach algebra, block structure, spectral triangle.

\section{REFERENCES}

[1] J. K. Finch, The single valued extension property on a Banach space, Pacific Jour. Math. 58 (1975) 61-69.

[2] R. E. HaRTE AND A. W. Wickstead, Boundaries, hulls and spectral mapping theorems, Proc. Royal Irish Acad. 81A (1981) 201-208.

[3] R. E. HARTE, Invertibility and singularity, Dekker 1988.

[4] R. E. HARTE, Invertibility and singularity for operator matrices, Proc. Royal Irish Acad. 88A (1988) 103-188.

[5] R. E. HARTE, Block diagonalization in Banach algebras, Proc. Amer. Math. Soc. 129 (2001) 181-190.

[6] R. E. HARTE, Arens-Royden and the spectral landscape, Filomat (Nis) 16 (2002) 31-42.

[7] R. E. Harte And C. HeRnAndeZ, Adjugates in Banach algebras, Proc. Amer. Math. Soc. 134 (2005) 1397-1404.

[8] H.-K. Du AND J. PAN, Perturbations of spectrums of $2 \times 2$ operator matrices, Proc. Amer. Math. Soc. 121 (1994) 761-766.

[9] J. K. HAN, H. Y. LEE AND W. Y. LEE, Invertible completions of $2 \times 2$ upper triangular operator matrices, Proc. Amer. Math. Soc. 128 (2000) 119-123.

[10] M. Houimdi And H. Zguitti, Propriétés spectrales locales d'une matrice carree des operateurs, Acta Math. Vietnamica 25 (2000) 137-144.

[11] S. V. DJORDJEVIC AND Y. M. HAN, A note on Weyl's theorem for operator matrices, Proc. Amer. Math. Soc. 131 (2003) 2543-2547.

[12] I. H. JEON AND J. W. LEE, Weyl's theorem for operator matrices and the single valued extension property, Glasgow Math. Jour. 48 (2006) 567-573.

[13] H. RADJAVI AND P. ROSENTHAL, Invariant subspaces, Springer 1973.

[14] P. AIENA AND M. GonZALEZ, Essentially incomparable Banach spaces and Fredholm theory, Proc. Royal Irish Acad. 93A (1993) 49-59.

[15] M. GonZALEZ, On essentially incomparable Banach spaces, Math. Zeit. 215 (1994) 621-629. 